\title{
OBOWIAZZEK WSPÓŁDZIAŁANIA PRACODAWCY Z WŁAŚCIWĄ WŁADZĄ PUBLICZNĄ W SPRAWIE ZWOLNIENIA GRUPOWEGO JAKO ŚRODEK SPOŁECZNEJ OCHRONY MIEJSC PRACY (ZATRUDNIENIA)
}

\begin{abstract}
Obligation of the employer to cooperate with the competent public authority on collective redundancy as a means of social protection of workplaces (employment)

This article discusses the issue of the employer's obligation to cooperate with public authorities in the case of collective redundancies, which is a means of social protection of employment relationships. The author first explains the concept of social protection of workplaces, pointing out that one of its instruments is the obligation to notify the competent employment authorities of the intended collective redundancy. Furthermore, the paper analyses the regulations of abovementioned employer's obligation under ILO Law (Convention No. 158) and the European Union Law (Directive 98/59/EC). Thereafter, the author discusses the relevant regulations contained in the Act of March 13, 2013 on specific terms and conditions for terminating employment relationships with employees for reasons not related to the employees, subjecting above mentioned regulations to critical analysis and examining whether the adopted manner of regulating this obligation allows it to be an effective, proactive means of social protection of employment.
\end{abstract}

Słowa kluczowe: społeczna ochrona zatrudnienia, zwolnienia grupowe, dyrektywa 98/59/WE, powiatowy urząd pracy, zawiadomienie o zwolnieniu grupowym

Key words: social protection of employment, collective redundancies, Directive 98/59/EC, district labour office, notification of collective redundancies

\section{Pojęcie i środki społecznej ochrony zatrudnienia}

W nauce prawa pracy można wyróżnić dwa podejścia do ochrony trwałości stosunku pracy i środków służących jej realizacji: tradycyjne, wąskie, postrzegające ochronę $\mathrm{w}$ kategoriach stabilizacji indywidualnego stosunku pracy, oraz szersze, utożsamiające ochronę z tak zwaną ochroną społeczną miejsc pracy ${ }^{1}$. Tradycyjna ochrona trwałości

1 Por. Z. Hajn, Ochrona miejsc pracy a interes pracodawców, w: Prawo pracy a bezrobocie, L. Florek (red.), Warszawa 2003, s. 25; H. Szewczyk, Powszechna ochrona trwałości umownego stosunku pracy po nowelizacji kodeksu pracy, Z Problematyki Prawa Pracy i Polityki Socjalnej, t. XIII, Katowice 1998, s. 24 i n. 
stosunku pracy jest rozumiana jako zespół środków prawnych ograniczających swobodę pracodawcy w zakresie rozwiązywania indywidualnego stosunku pracy, co oznacza, że jest ukierunkowana na ochronę zatrudnienia jednostkowego pracownika przed utratą pracy (tak zwana indywidualna ochrona miejsc pracy). Tego typu ochrona koncentruje się zatem na środkach prawnych zapewniających stabilizację indywidualnego stosunku pracy. W polskim prawie pracy składają się na nią uzależnienie dopuszczalności jednostronnego rozwiązania stosunku pracy przez pracodawcę od istnienia przyczyny uzasadniającej wypowiedzenie (rozwiązanie), wymóg konsultacji zamiaru wypowiedzenia lub rozwiązania z reprezentującą pracownika organizacją związkową, a także bezwzględne i względne zakazy wypowiadania lub wypowiadania i rozwiązywania stosunku pracy (ochrona szczególna). W istocie rzeczy mechanizmy prawne działania tych środków sprowadzają się do mniej lub dalej idącego ograniczenia wolności pracodawcy w zakresie wypowiadania lub rozwiązywania stosunku pracy. Tradycyjna ochrona trwałości stosunku pracy nie jest w pełni skuteczna jako środek przeciwdziałający utracie miejsc pracy. Przykładowo, zakaz wypowiedzenia lub rozwiązania stosunku pracy zmusza wprawdzie pracodawcę do dalszego zatrudniania pracownika objętego ochroną, pomimo że na pracę na jego stanowisku z przyczyn obiektywnych nie ma zapotrzebowania, ale w to miejsce pracodawca może zwolnić innego pracownika, który jest w mniejszym stopniu chroniony. W konsekwencji w praktyce i tak może dojść do zwolnienia pracownika i utraty realnego miejsca pracy².

Ochrona trwałości stosunku pracy może być jednak pojmowana szerzej, jako tak zwana społeczna ochrona miejsc pracy, obejmująca ogół rozwiązań prawnych zmniejszających w skali społecznej (zakładu pracy, miejscowości regionu, kraju) liczbę zwolnień z pracy oraz sprzyjających zatrudnieniu ${ }^{3}$. Ochrona miejsc pracy w tym znaczeniu oznacza działania służące zachowaniu miejsc pracy, które już istnieją, zamianie miejsc pracy na inne lub stworzenie nowych miejsc pracy, co może być skutkiem np. restrukturyzacji zakładu pracy, inwestycji, działań władzy publicznej ${ }^{4}$. W tym kontekście tradycyjna ochrona trwałości stosunku pracy jawi się jako jeden z elementów szerzej pojętej społecznej ochrony miejsc pracy. Tak rozumiana społeczna ochrona wykracza poza przepisy prawa pracy, dotyczące bezpośrednio wypowiadania lub rozwiązywania umów o pracę. Obejmuje ona bowiem także środki prawne tworzące instrumentarium przeciwdziałania bezrobociu oraz działania antykryzysowe ${ }^{5}$. Ochrona w szerokim znaczeniu obejmuje zatem nie tylko środki ograniczające swobodę wypowiedzenia lub rozwiązania indywidualnego stosunku pracy, ale także środki wpływające na zwiększenie możliwości uzyskania pracy przez pracowników oraz zachowanie istniejących miejsc pracy. Pomimo kontrowersji

2 Por. A. Sobczyk, Prawo pracy w świetle Konstytucji RP, t. II, Wybrane problemy i instytucje prawa pracy a konstytucyjne prawa i wolności człowieka, Warszawa 2013, s. 95.

3 Tak na przykład Z. Hajn, Ochrona miejsc pracy..., s. 26.

4 Por. L. Florek, Ochrona miejsc pracy a interesy pracowników, pracodawców i bezrobotnych, w: Prawo pracy a bezrobocie, L. Florek (red.), Warszawa 2003, s. 11.

5 Zob. szerzej Z. Hajn, Ochrona miejsc pracy..., s. 26-27 i powołane tam dokumenty międzynarodowe dotyczące zatrudnienia i bezrobocia oraz piśmiennictwo. 
można przyjąć, że służą one utrzymaniu zatrudnienia i tworzeniu miejsc pracy w skali społecznej - szeroko rozumianego rynku pracy ${ }^{6}$.

Do środków prawnych ochrony trwałości stosunku pracy w przedstawionym wyżej szerszym rozumieniu, a więc służących społecznej ochronie miejsc pracy, należy zaliczyć także obowiązek powiadomienia publicznych, właściwych organów zatrudnienia o zamierzonym zwolnieniu grupowym ${ }^{7}$. Wskazany obowiązek przewidywała już ustawa z 1989 r. o szczególnych zasadach rozwiązywania z pracownikami stosunków pracy z przyczyn dotyczących zakładu pracy oraz o zmianie niektórych ustaw ${ }^{8}$. Zgodnie $z$ art. 3 powołanej ustawy pracodawca był zobowiązany zawiadomić o zamierzonym zwolnieniu grupowym organ zatrudnienia stopnia podstawowego nie później niż na 45 dni przed terminem dokonywania wypowiedzeń. Zawiadomienie miało charakter jednorazowy i w zasadzie wyczerpywało procedurę kontaktów pracodawcy z organem zatrudnienia w sprawie dokonania zwolnienia grupowego. Ustawa nie precyzowała bliżej treści oraz formy dokonania przez pracodawcę zawiadomienia o zamierzonym zwolnieniu grupowym. Co do zasady, obowiązek ten został przeniesiony, z pewnymi modyfikacjami, na grunt nowej ustawy z 13 marca 2003 r. o szczególnych zasadach rozwiązywania z pracownikami stosunków pracy z przyczyn niedotyczących pracowników ${ }^{9}$, zwanej dalej ustawą o „zwolnieniach grupowych".

O ile ogólnie należy przyjąć, że przewidziane przez polskiego ustawodawcę rozwiązania spełniają standardy określone w prawie Międzynarodowej Organizacji Pracy (MOP) i wspólnotowe, to dostosowanie uregulowań do tych standardów w takich kwestiach, jak: pozycja prawna organu władzy publicznej oraz jego uprawnienia w sprawach zwolnień grupowych, nasuwają pewne refleksje. Rodzi się bowiem pytanie, czy polski ustawodawca w pełni wykorzystał możliwości wynikające z prawa MOP oraz prawa wspólnotowego, aby obowiązek ten mógł odgrywać rolę skutecznego, aktywnego środka społecznej ochrony miejsc pracy, o większym znaczeniu aniżeli na gruncie ustawy z $1989 \mathrm{r}$.

6 Z. Hajn, Ochrona miejsc pracy..., s. 27.

7 Zob. A. Rycak, Powszechna ochrona trwałości stosunku pracy, Warszawa 2013, s. 193; A. Dral, Powszechna ochrona trwałości stosunku pracy. Tendencje zmian, Warszawa 2009, s. 101-102.

8 Dz. U. z 1990 r., Nr 4, poz. 19 ze zm.

9 Tekst jedn. Dz. U. z 2016 r., poz. 1474 ze zm. 


\section{Obowiązek powiadomienia publicznych, właściwych organów zatrudnienia o zamierzonym zwolnieniu grupowym w prawie MOP i Unii Europejskiej}

\section{Obowiązek powiadomienia publicznego właściwych organów o zamierzonym zwolnieniu grupowym w prawie MOP}

Według art.14 Konwencji nr 158 MOP dotyczącej rozwiązania stosunku pracy z inicjatywy pracodawcy ${ }^{10}$, jeżeli pracodawca rozważa dokonanie zwolnień z przyczyn o charakterze gospodarczym, technologicznym, strukturalnym lub podobnym, ma obowiązek zawiadomienia o tym zamiarze możliwie najwcześniej właściwej władzy, zgodnie z ustawodawstwem i praktyką krajową, podając odpowiednie informacje, obejmujące pisemne oświadczenie o przyczynach zwolnień, liczbie i kategoriach pracowników, których mogą one dotyczyć, i o okresie, w którym zamierzone zwolnienia zostaną dokonane. Ustawodawstwo krajowe może ograniczyć stosowanie tego obowiązku do przypadków, gdy liczba pracowników, których zwolnienie jest rozważane, równa się co najmniej określonej liczbie lub określonemu procentowi pracowników. Obowiązek zawiadomienia właściwej władzy o zwolnieniach powinien być zrealizowany w minimalnym okresie przed ich dokonaniem, ustalanym przez ustawodawstwo krajowe. Należy, jak się wydaje, przyjąć, że konwencja przewiduje dwa obowiązkowe zawiadomienia władzy publicznej o zwolnieniu grupowym: pierwsze na etapie rozważania zwolnień przez pracodawcę, drugie natomiast przed ich dokonaniem. Konwencja nie precyzuje jednak dokładnie, w jakim czasie powinny one nastąpić, zwłaszcza czy pracodawca powinien zawiadomić właściwą władzę przed konsultacjami, czy po konsultacjach z przedstawicielami pracowników. Konwencja nie przesądza roli, jaką powinien odgrywać organ władzy publicznej w procedurze zwolnień ${ }^{11}$. Zalecenie nr $166 \mathrm{MOP}$ o rozwiązaniu stosunku pracy $\mathrm{z}$ inicjatywy pracodawcy jest $\mathrm{w}$ tej kwestii bardziej konkretne. W rozdziale III wskazuje, że jeżeli jest to właściwa władza publiczna, powinna „pomagać” stronom $\mathrm{w}$ poszukiwaniu rozwiązań problemów powstających $\mathrm{w}$ związku $\mathrm{z}$ rozważanymi przez pracodawcę zwolnieniami grupowymi. Zalecenie przewiduje zatem bardziej aktywną rolę dla organów władzy publicznej aniżeli konwencja nr 158. W myśl $₫ 25$ ust. 1 zalecenia właściwa władza powinna podjąć środki stosowne do warunków w danym kraju w celu popierania działań zmierzających do znalezienia zwalnianym pracownikom innego stosownego zatrudnienia, tak szybko, jak to jest możliwe po ewentualnym przeszkoleniu lub przekwalifikowaniu. Zalecenie statuuje zasadę, że znalezienie nowego zatrudnienia zwalnianemu pracownikowi powinno być promowane przez aktywną działalność władzy publicznej. Właściwa władza powinna podejmować właściwe środki we współpracy z przedstawicielami pracowników i pracodawcą. Rozwiązanie to narzuca w pewnym stopniu stronom i organowi władzy publicznej trójstronną partycypację

\footnotetext{
10 Nieratyfikowana przez Polskę.

11 A. Rycak, Powszechna ochrona..., s. 152-153.
} 
w poszukiwaniu sposobów złagodzenia skutków zwolnień i ma mobilizować władzę publiczną do współpracy z pracodawcami i przedstawicielami pracowników w celu znalezienia nowych miejsc pracy ${ }^{12}$.

Pomimo tej konkretyzacji należy stwierdzić, że przytoczone wyżej uregulowania Konwencji 158 i zalecenia 166 charakteryzuje bardzo duży stopień ogólności i w konsekwencji brak bliższego wyjaśnienia, co należy rozumieć pod pojęciem właściwej władzy, a zwłaszcza - co jest szczególnie istotne - na czym powinna polegać owa "pomoc" stronom oraz w jakich formach, poza wskazanymi w zaleceniu, powinna być realizowana ${ }^{13}$. Z zalecenia można jedynie wyprowadzić ogólne wskazanie kierunkowe, że pomoc powinna dotyczyć „problemów powstających w związku ze zwolnieniem”. Należy dodać, iż akcent na „pomoc” oznacza, jak się wydaje, że pierwszoplanowa rola $\mathrm{w}$ rozwiązywaniu problemów związanych ze zwolnieniem grupowym przypada stronom, a więc pracodawcy i przedstawicielstwu pracowniczemu, właściwa władza powinna natomiast aktywnie wesprzeć te działania na zasadzie pomocniczości.

\section{Obowiązek powiadomienia publicznego właściwych organów o zamierzonym zwolnieniu grupowym w prawie Unii Europejskiej}

Wobec nieratyfikowania przez Polskę Konwencji 158 MOP zasadnicze znaczenie odgrywają standardy unijne, określone w dyrektywie 98/59/WE z 20 lipca 1998 r. w sprawie zbliżenia prawa państw członkowskich w zakresie zwolnień grupowych ${ }^{14}$.

Regulacje dyrektywy dotyczące obowiązków pracodawcy związanych z procedurą zwolnień grupowych, podobnie jak i MOP, nie są precyzyjne. Nie ulega jednak wątpliwości, że według art. 3 dyrektywy 98/59/WE zawartego w sekcji III zatytułowanej „Procedura zwolnień grupowych" pracodawca jest zobowiązany do zawiadomienia (notyfikowania) na piśmie właściwemu organowi władzy publicznej o każdym zamiarze zwolnienia grupowego. Przy czym - w świetle dyrektywy w relacjach pracodawcy z właściwą władzą publiczną w sprawie zwolnienia grupowego - należy wyraźnie wyróżnić dwie odrębne powinności: przekazanie informacji o zwolnieniu i notyfikację zwolnienia grupowego władzy publicznej. Jak się wydaje, powinności te są niezależnymi elementami procedury zwolnień, które jednocześnie się dopełniają.

\section{a. Przekazanie organowi władzy publicznej kopii informacji o zwolnieniu grupowym przekazanych przedstawicielom pracowników}

Zgodnie z art. 2 dyrektywy 98/59/WE regulującym obowiązki informacyjno-konsultacyjne związane ze zwolnieniem grupowym, określone w sekcji II dyrektywy zatytułowanej „informacja i konsultacja”, pracodawca ma obowiązek przesłania właściwemu organowi władzy publicznej kopii notyfikacji kierowanej do przedstawicieli pracowników, zawierającej przynajmniej takie dane, jak: przyczyny zamierzonego zwolnienia; liczby

\footnotetext{
12 Por. tamże, s. 156.

13 Por. tamże.

14 Dz. U. WE L 225 z dnia 12 sierpnia 1998 r., s. 16.
} 
kategorii pracowników przewidzianych do zwolnienia; liczby i kategorii pracowników zwykle zatrudnionych; okres, w którym przewidziane są zwolnienia; przewidziane kryteria selekcji pracowników, którzy mają zostać zwolnieni, o ile ustawodawstwo i/lub praktyka krajowa dają taką możliwość pracodawcy. Kopię notyfikacji kierowanej do przedstawicielstwa pracowników pracodawca ma obowiązek dostarczyć właściwemu organowi władzy publicznej niezależnie od obowiązku notyfikacji ${ }^{15}$.

Na tle omawianego obowiązku pojawiają się następujące kwestie. Przede wszystkim dyrektywa 98/59/WE nie rozstrzyga, jaki organ władzy publicznej jest właściwy w sprawie zwolnienia grupowego, pozostawiając decyzję w tej sprawie państwom członkowskim. Z punktu widzenia dyrektywy istotne jest, aby organ miał status organu władzy publicznej. Biorąc po uwagę cel omawianych obowiązków pracodawcy wobec władzy publicznej, jakim jest przeciwdziałanie negatywnym skutkom zwolnień grupowych na lokalnych rynkach pracy, powinny to być organy właściwe do spraw administracji pracy (urzędy pracy), które posiadają kompetencje władcze oraz dysponują środkami finansowymi i organizacyjnymi pozwalającymi na wspieranie lokalnego rynku pracy ${ }^{16}$.

Dyrektywa 98/59/WE nie określa również terminu przekazania kopii informacji właściwemu organowi władzy publicznej. Z pragmatycznego punktu widzenia należy przyjąć, że powinno to nastąpić z odpowiednim wyprzedzeniem, a najlepiej w tym samym czasie co notyfikowanie przedstawicieli pracowników. Jedynie bowiem w tej sytuacji istnieje realna możliwość przygotowania i podjęcia przez władzę publiczną stosownych działań mających zapewnić skuteczną, odpowiednią pomoc zwalnianym pracownikom.

W myśl dyrektywy 98/59/WE realizacja obowiązku przekazania informacji jest niezależna od faktu, czy decyzja dotycząca zwolnień grupowych pochodzi od pracodawcy, czy też podejmuje ją przedsiębiorstwo, które sprawuje kontrolę nad pracodawcą. Należy podkreślić, że przy rozpatrywaniu naruszeń obowiązków informacyjnych i notyfikacji dyrektywa stanowi, że nie uwzględnia się jakichkolwiek uzasadnień ze strony pracodawcy opierających się na fakcie, iż przedsiębiorstwo, które podjęło decyzję prowadzącą do zwolnień grupowych, nie dostarczyło mu wymaganych informacji (art. 2 ust. 4 dyrektywy).

\section{b. Notyfikacja zwolnienia grupowego właściwemu organowi władzy publicznej}

Kolejna, wyraźnie wyodrębniona w prawie wspólnotowym powinność pracodawcy, to notyfikacja zwolnienia grupowego właściwej władzy publicznej.

Przede wszystkim pracodawca ma obowiązek notyfikowania na piśmie właściwemu organowi władzy publicznej o każdym zamiarze zwolnienia grupowego. Państwa członkowskie mogą jednak postanowić, że w przypadku zamiaru zwolnienia grupowego związanego z zaprzestaniem działalności przedsiębiorstwa $\mathrm{w}$ rezultacie orzeczenia sądowego (upadłość) pracodawca jest zobowiązany notyfikować na piśmie właściwemu

15 L. Krysińska-Wnuk, Regulacja zwolnień grupowych pracowników, Warszawa 2009, s. 55.

16 Tamże, s. 54. 
organowi władzy publicznej, jedynie w przypadku gdy ta ostatnia wystąpi z odpowiednim wnioskiem.

Dyrektywa 98/59/WE nie definiuje pojęcia notyfikacji. Należy przyjąć, że notyfikacja oznacza urzędowe zawiadomienie o ważnych faktach właściwego organu, w tym przypadku właściwego organu władzy publicznej, o faktach związanych ze zwolnieniem grupowym. Notyfikacja powinna zawierać wszystkie istotne informacje dotyczące planowanych zwolnień i konsultacji z przedstawicielami pracowników, określone w art. 2 dyrektywy, w szczególności winna wskazywać przyczyny zwolnień, liczbę pracowników przewidzianych do zwolnienia, liczbę zwykle zatrudnionych pracowników i okres, w którym przewiduje się przeprowadzenie zwolnień. Kopię notyfikacji pracodawca jest zobowiązany przekazać przedstawicielom pracowników, którzy mogą bezpośrednio przekazać swoje ewentualne uwagi dotyczące planowanego zwolnienia grupowego do organu władzy publicznej. Celem tego rozwiązania jest umożliwienie wzajemnej weryfikacji informacji przekazanych przedstawicielom pracowników oraz właściwemu organowi władzy publicznej i w konsekwencji uniemożliwienie pracodawcy doręczenia wiadomości o różnej treści tym podmiotom. Ich zadaniem powinno być bowiem współdziałanie z pracodawcą w opracowaniu środków i sposobów pozwalających na uniknięcie zwolnień grupowych lub ich ograniczenie ${ }^{17}$. Dyrektywa 98/59/WE nie przyznaje natomiast właściwemu organowi władzy publicznej prawa do zwrócenia się do przedstawicielstwa pracowniczego w okresie poprzedzającym podjęcie przez pracodawcę decyzji o zwolnieniu grupowym ${ }^{18}$.

Zwolnienia nie mogą nastąpić wcześniej niż po upływie określonego czasu od notyfikacji zwolnienia właściwemu organowi władzy publicznej. Jak stanowi art. 4 ust. 1 dyrektywy, zwolnienia grupowe, o których został notyfikowany organ władzy publicznej, nie mogą być przeprowadzone wcześniej niż po upływie 30 dni od notyfikacji, przy czym powinno to nastąpić bez naruszenia przepisów o indywidualnych okresach wypowiedzenia.

Na potrzeby wykładni art. 2-4 dyrektywy 98/59/WE przez zwolnienie należy rozumieć wyrażenie przez pracodawcę woli rozwiązania umowy o pracę, a więc czynność prawną zmierzającą do rozwiązania stosunku pracy (wyrok ETS w sprawie C-188/03 Irmtraud Junk $v$. Wolfgang Kuhnel). Wątpliwość będąca przedmiotem wypowiedzi trybunału powstała w związku z tym, czy termin „zwolnienie” oznacza czynność prawną wypowiedzenia umowy o pracę, czy też oznacza zakończenie stosunku pracy po upływie okresu wypowiedzenia.

Z punktu widzenia społecznej ochrony miejsc pracy (zatrudnienia) najistotniejszy jest jednak aspekt związany z celem ustanowienia czasu, jaki musi upłynąć między notyfikacją a zwolnieniami. W myśl dyrektywy 98/59/WE celem tego rozwiązania jest danie władzy publicznej czasu, który powinien być wykorzystany na znalezienie rozwiązań problemów związanych z planowanymi zwolnieniami grupowymi.

17 A. Świątkowski, Restrukturyzacja zakładu pracy. Komentarz, Kraków 2003, s. 65.

18 Tamże. 
Pomimo że dyrektywa nie wskazuje wprost, na czym działania organu władzy publicznej mają w praktyce polegać, należy przyjąć, że zamiarem prawodawcy wspólnotowego było wyznaczenie właściwemu organowi władzy publicznej roli aktywnego podmiotu w sprawie zwolnień grupowych. Zakres środków zależy od tego, jaki organ władzy państwowej jest właściwy w sprawie zwolnień grupowych. W przypadku organów do spraw zatrudnienia, co w zasadzie jest regułą w państwach Unii Europejskiej, będą to działania mające na celu uruchomienie aktywnych i nieaktywnych form przeciwdziałania bezrobociu. W praktyce chodzi między innymi o takie działania, jak znalezienie na rynku pracy i zaproponowanie zwalnianym pracownikom nowych miejsc pracy, wypracowanie innych propozycji zapewnienia pracy lub stwarzających szerszą perspektywę jej podjęcia (roboty publiczne, prace interwencyjne, przekwalifikowania pracowników, staże, kursy, szkolenia, studia podyplomowe). Działania te powinny zaowocować uzyskaniem nowego zatrudnienia lub utrzymaniem dotychczasowego, np. poprzez podniesienie kwalifikacji pracowników w sytuacji, gdy zwolnienia są podyktowane wprowadzeniem nowych technologii, do których zatrudnieni pracownicy nie mają wystarczających kwalifikacji.

Nie ulega zatem wątpliwości, że notyfikacji w procedurze zwolnień należy przypisać ważną rolę. Wydaje się, że jest ona nie mniej istotna aniżeli konsultacja z przedstawicielami pracowników. W pewnym stopniu wyjaśniałoby to powiązanie rozpoczęcia zwolnień grupowych z notyfikacją zwolnienia właściwemu organowi władzy publicznej, a nie z zawiadomieniem przedstawicieli pracowników o planowanym zwolnieniu i konsultacją ${ }^{19}$.

Zgodnie z dyrektywą zakres możliwej aktywności organu władzy publicznej może być przez państwo członkowskie poszerzony. Przede wszystkim państwo członkowskie może zezwolić właściwemu organowi władzy publicznej na skrócenie lub przedłużenie okresu 30 dni, jaki musi upłynąć od dnia notyfikacji zwolnienia właściwemu organowi, do dnia kiedy mogą nastąpić zwolnienia.

Skrócenie terminu przez organ władzy publicznej nie zostało uwarunkowane żadnymi konkretnie sformułowanymi przesłankami. Dyrektywa 98/59/WE nie formułuje także żadnych wskazówek dotyczących kompetencji organów władzy publicznej do podjęcia takiej decyzji. W szczególności powstaje pytanie, czy upoważnienie takie może mieć charakter stały, czy też powinno być wydawane ad hoc. Wobec braku ograniczeń w tym zakresie statuowanych przez dyrektywę należy przyjąć, że państwa członkowskie są upoważnione do samodzielnego uregulowania tego problemu.

Przedłużenie terminu jest natomiast możliwe w sytuacji, gdy czas między notyfikacją zwolnienia właściwemu organowi władzy publicznej a zwolnieniami grupowymi, przewidziany w ustawodawstwie krajowym, jest krótszy niż $60 \mathrm{dni}$. W takim przypadku państwo może upoważnić organ władzy publicznej do jego przedłużenia do 60 dni, jeżeli istnieje ryzyko, że problemy powstałe w następstwie zamierzonych zwolnień mogą nie zostać rozwiązane w pierwotnym terminie $30 \mathrm{dni}$. Celem tego rozwiązania jest danie organowi władzy publicznej dodatkowego czasu dla wypracowania decyzji, podjęcia działań ochronnych, jeżeli okres pierwotny jest w praktyce zbyt krótki.

19 Odmiennie A. Świątkowski, Tamże..., s. 65-66. 
Ponadto na mocy omawianej dyrektywy państwa członkowskie mają prawo przyznania organowi władzy publicznej uprawnienia do dalszego przedłużenia tego terminu. Przed wygaśnięciem pierwotnego terminu, krótszego niż 60 dni, właściwy organ musi jednak powiadomić pracodawcę o jego przedłużeniu i przyczynach podjętej decyzji. Dyrektywa nie wskazuje, na jaki termin okres poprzedzający podjęcie przez pracodawcę decyzji o dokonaniu zwolnień grupowych może być przedłużony, ani nie ogranicza uprawnień do jego przedłużenia. Nasuwa się zatem pytanie, czy przedłużenie terminu zawiadomienia o planowanych zwolnieniach grupowych jest, czy też nie jest, ograniczone w czasie.

Jak już wyżej podkreślono, o podstawach decyzji powinien być poinformowany pracodawca, z podaniem przyczyn jej podjęcia. Dyrektywa nie określa natomiast uprawnień pracodawcy, którego decyzja dotyczy. Należy przyjąć, że przyznanie pracodawcy prawa do jej zaskarżenia zostało pozostawione poszczególnym państwom członkowskim.

Analizowane przepisy dyrektywy 98/59/WE nie przyznają natomiast organom władzy publicznej żadnych władczych uprawnień służących zablokowaniu lub zawieszeniu zwolnień grupowych, niezależnie od tego, jakie istotne przesłanki społeczne przemawiałyby za takim rozwiązaniem ${ }^{20}$. Właściwie w przypadku kontaktu pracodawcy z właściwym organem władzy publicznej organ ten poza prawem do uzyskania informacji o planowanym zwolnieniu grupowym oraz skróceniu, wydłużeniu terminu nie korzysta $\mathrm{z}$ innych uprawnień $^{21}$. Z tego powodu w doktrynie prawa pracy kompetencje organów władzy publicznej w sprawie zwolnień grupowych są oceniane jako „mniej intensywne”, a więc w konsekwencji słabsze niż przedstawicielstwa pracowniczego ${ }^{22}$. Należy dodać, że na etapie projektu dyrektywy rozważana była koncepcja przyznania właściwemu organowi administracji publicznej uprawnienia do akceptowania lub wyrażenia zastrzeżeń wobec zamiaru dokonania zwolnień grupowych. Wobec sprzeciwu Wielkiej Brytanii koncepcja ta nie została przyjęta ${ }^{23}$.

Państwo członkowskie może nie stosować ze względów praktycznych i prawnych przepisów ochronnych dotyczących terminu, jaki musi upłynąć od momentu notyfikacji do zwolnień grupowych, gdy zwolnienia następują w związku z zaprzestaniem działalności przedsiębiorstwa w wyniku decyzji sądu.

\section{Zawiadomienie i notyfikacja zwolnienia grupowego według ustawy z 2003 r. o zwolnieniach grupowych}

Na tle przedstawionych wyżej regulacji prawa wspólnotowego należy poddać analizie przepisy ustawy z 2003 r. o „zwolnieniach grupowych” dotyczące roli właściwego organu władzy publicznej w procesie dokonywania tych zwolnień i ochrony miejsc pracy. Jak

20 L. Krysińska-Wnuk, Regulacja zwolnień..., s. 55 i powołane tam orzecznictwo ETS.

${ }^{21}$ Szerzej zob. A. Świątkowski, Restrukturyzacja..., s. 65-66.

22 Tamże.

23 Tamże. 
już wyżej podkreślono, dyrektywa pozostawiła państwom członkowskim wskazanie właściwego organu w sprawach zwolnień grupowych. Polski ustawodawca powierzył tę rolę właściwym powiatowym urzędom pracy ${ }^{24}$, które wchodzą w skład powiatowej administracji zespolonej. Pojęcie właściwego powiatowego urzędu pracy budzi jednak w praktyce pewne wątpliwości. Nasuwa się bowiem pytanie, który urząd pracy należy uznać za właściwy jako adresata zawiadomienia i notyfikacji o zwolnieniu grupowym. A więc, czy jest to urząd właściwy dla siedziby pracodawcy, urząd właściwy dla miejsca wykonywania pracy przez zwalnianych pracowników czy też urząd właściwy dla miejsca zamieszkania zwalnianych pracowników.

Ogólnie przyjmuje się, że właściwym urzędem jest urząd właściwy dla siedziby pracodawcy. Rozważenia wymagałoby jednak, czy właściwym urzędem nie powinien być urząd właściwy dla miejsca zamieszkania zwalnianych pracowników.

Artykuł 2 ust. 6 ustawy z 2003 r. o „zwolnieniach grupowych” wymaga przekazania właściwemu powiatowemu urzędowi pracy informacji dotyczących zwolnienia grupowego $\mathrm{w}$ formie zawiadomienia. $\mathrm{W}$ doktrynie przyjmuje się, że powinno ono nastąpić na piśmie w tym samym terminie co zawiadomienie organizacji związkowych lub przedstawicieli pracowników ${ }^{25}$. Treść zawiadomienia została wyczerpująco określona przez ustawę o zwolnieniach grupowych. Co do zasady, stanowi ona odzwierciedlenie uregulowań dyrektywy 98/59/WE i ogólnie nie budzi zastrzeżeń, z wyjątkiem informacji dotyczących przyczyn zwolnienia i kryteriów doboru pracowników do zwolnienia. Przekazanie tego typu informacji urzędom pracy, pomimo że zgodne z dyrektywą, jest uważane za zbyt daleko ingerujące w wolność podejmowania decyzji związanych $\mathrm{z}$ zarządzaniem przedsiębiorstwem ${ }^{26}$.

Notyfikacja (zawiadomienie) zwolnienia grupowego powiatowemu urzędowi pracy powinna nastąpić niezwłocznie po zawarciu porozumienia bądź wydaniu regulaminu w sprawie zwolnień grupowych (art. 4 ust. 1 ustawy) ${ }^{27}$. Należy zauważyć, że polski ustawodawca posługuje się terminem „zawiadomienie”, a nie - tak jak dyrektywa - terminem „notyfikacja”. Termin „,zawiadomienie” oznacza przekazanie komuś wiadomości, informacji ${ }^{28}$. Notyfikacja natomiast to oficjalne, urzędowe zawiadomienie o czymś bardzo istotnym, np. w dyplomacji podanie innemu państwu ważnego urzędowego faktu ${ }^{29}$. Terminy te nie są zatem synonimami. Nie ulega zatem wątpliwości, że pojęciu notyfikacji należy przypisać formalnie większą wagę aniżeli zawiadomieniu. Należy zatem postawić

$24 \mathrm{~W}$ polskich realiach rolę tę mogłaby także pełnić Państwowa Inspekcja Pracy. Zob. K. Walczak, w: Zbiorowe prawo pracy. Komentarz, J. Wratny, K. Walczak (red.), Warszawa 2009, s. 492 i powołana tam literatura.

25 A. Wypych-Żywicka, w: System prawa pracy, t. V, Zbiorowe prawo pracy, K.W. Baran (red.), Warszawa 2014, s. 1013.

26 Por. Tamże, s. 1014.

27 Szerzej zob. K. Walczak, ..., s. 482-484 i 493; K.W. Baran, Procedura zwolnień grupowych, Studia z Zakresu Prawa Pracy 2003/2004, s. 96.

28 Zob. Słownik współczesnego języka polskiego, t. II, Przegląd Reader’s Digest, Warszawa 1998, s. 635.

29 Zob. Słownik wyrazów obcych. Wydanie nowe, E. Sobol (red.), Warszawa 1977, s. 777. 
pytanie, czy zastosowana terminologia jest dziełem przypadku, czy jest to celowy zabieg ustawodawcy, za pomocą którego dążył on do ograniczenia odpowiedzialności państwa za rozwiązywanie problemów związanych ze zwolnieniami grupowymi.

Zwolnienia grupowe mogą być dokonane dopiero po upływie 30 dni od zawiadomienia (ustawa z 1989 r. zawierała w tej sprawie podobne regulacje). Dopuszczenie się przez pracodawcę naruszenia obowiązków w tym zakresie należy traktować jako naruszenie wymogów formalnych dotyczących procedury dokonania zwolnienia grupowego.

W tym miejscu nasuwa się kwestia, czy i w jakich sferach występują różnice między standardami wspólnotowymi a polskimi przewidzianymi w ustawie z 2003 r. o zwolnieniach grupowych, mającymi wpływ na pozycję władzy publicznej w procesie zwolnień grupowych i w konsekwencji na skuteczność ochrony społecznej miejsc pracy.

Pierwsza, zasadnicza różnica dotyczy określenia przez polskiego ustawodawcę pozycji prawnej organu władzy publicznej, jakim jest powiatowy urząd pracy przy zwolnieniach grupowych, w zasadzie jako mało aktywnej (biernej). Zgodnie z art. 2 ust. 6 ustawy o zwolnieniach grupowych powiatowy urząd pracy został bowiem obsadzony przez ustawodawcę $\mathrm{w}$ roli podmiotu przyjmującego zawartą $\mathrm{w}$ zawiadomieniu informację o zamierzonym zwolnieniu grupowym. Przedstawiona wyżej dyrektywa wspólnotowa przewiduje natomiast dla władzy publicznej rolę aktywną. Przede wszystkim organ władzy publicznej powinien wykorzystać ten czas do rozwiązania problemów związanych z zamierzonymi zwolnieniami grupowymi, a więc powinien czynnie włączyć się w działania związane ze zwolnieniem grupowym. Już na gruncie ustawy z $1989 \mathrm{r}$. o zwolnieniach grupowych $w$ nauce prawa pracy zwrócono uwagę na duże znaczenie roli organu zatrudnienia w zakresie zwolnień grupowych ${ }^{30}$.

Z punktu widzenia ochrony społecznej miejsc pracy aktywności organu władzy publicznej w zakresie zwolnień grupowych należy przypisać zasadnicze znaczenie dla pracowników tracących pracę i polityki społecznej. Wprawdzie przy dokonywaniu wykładni przytoczonych wyżej przepisów ustawy z 2003 r. przyjmuje się w nauce prawa pracy, że zarówno pierwsze, jak i drugie zawiadomienie powiatowego urzędu pracy służy efektywnemu przygotowaniu się urzędu do realizacji zadań związanych ze zwolnieniem, a więc rejestracji bezrobotnych, udzielania pomocy w znalezieniu pracy, szkoleń, przekwalifikowania, to jednak interpretacja ta nie ma wyraźnego, mocnego oparcia w obowiązujących przepisach ustawowych. Reasumując, w świetle obecnego stanu prawnego na powiatowym urzędzie pracy (organie władzy publicznej) nie ciąży, poza przyjęciem do wiadomości zawiadomienia informującego o zamierzonym zwolnieniu, wprost sformułowany obowiązek podejmowania działań w celu rozwiązania problemów, jakie wiążą się z zamierzonym przez pracodawcę zwolnieniem grupowym. Stan ten pozostaje zatem $\mathrm{w}$ dysharmonii z uregulowaniami wspólnotowej dyrektywy 98/59/ WE. Należy podkreślić wyrażony w nauce prawa pracy pogląd, że celem dyrektywy o zwolnieniach grupowych było wyznaczenie organom władzy publicznej roli równie

30 H. Szurgacz, Dostosowanie prawa pracy do prawa europejskiego w świetle Układu Europejskiego, Państwo i Prawo 1998, 1, s. 45. 
ważnej, a może nawet ważniejszej, niż procedurom konsultacyjnym z przedstawicielstwem pracowniczym $^{31}$. Od wyczerpania procedury zawiadamiania władzy publicznej zarówno dyrektywa, jak i ustawa uzależniają możliwość dokonywania zwolnień grupowych.

Polski ustawodawca, wzorem prawa wspólnotowego, nie przyznaje powiatowemu urzędowi pracy żadnych uprawnień do ingerencji w decyzje pracodawcy w sprawie przeprowadzenia zwolnień w postaci wstrzymania zwolnień lub ich ograniczenia.

Należy zatem przyjąć, że formalnie standardy dotyczące udziału powiatowego urzędu pracy $\mathrm{w}$ zwalnianiu pracowników z przyczyn niedotyczących pracowników, przewidziane $w$ art. 3 dyrektywy 98/59/WE, zostały dochowane (pisemne zawiadomienie, treść zawiadomienia, przekazanie kopii zawiadomienia związkom zawodowym, termin zwolnień). Nie określono natomiast w sposób wyraźny, tak jak wymagają tego standardy dyrektywy, roli organu władzy publicznej w zakresie zwolnień grupowych jako aktywnej w zakresie rozwiązywania problemów związanych ze zwolnieniem.

Oprócz standardów dotyczących udziału władzy publicznej w zwolnieniach grupowych, które dane państwo jest zobowiązane wprowadzić, wspólnotowa dyrektywa 98/59/WE przewiduje także takie, których wprowadzenie jest pozostawione uznaniu państwa członkowskiego. Dotyczą one możliwości przedłużenia terminu zwolnień. Polski ustawodawca nie skorzystał z możliwości przyznania powiatowym urzędom pracy uprawnień ani do skrócenia 30-dniowego terminu, ani też do jego przedłużenia, na co zezwala art. 4 ust. 1 i 3 dyrektywy 98/59/WE.

Formalnie brak takich rozwiązań w polskim prawie normującym zwolnienia grupowe nie stanowi naruszenia dyrektywy, ich wprowadzenie zależy bowiem od decyzji danego państwa członkowskiego. Odmienny pogląd w tej sprawie jest nieuprawniony, dyrektywa bowiem w sposób wyraźny przewiduje, że państwa członkowskie mogą takie rozwiązania wprowadzić, ale nie muszą. Niewyposażenie powiatowych urzędów pracy w tego typu uprawnienie należy jednak ocenić negatywnie. Uprawnienie do skrócenia, a zwłaszcza do przedłużenia terminu, mogłoby bowiem odgrywać pozytywną rolę, służąc większej elastyczności w zakresie dokonywania zwolnien. Wprowadzenie takiego rozwiązania zwiększałoby uprawnienia powiatowych urzędów pracy w zakresie zwolnień grupowych, przyczyniając się do uaktywnienia urzędu pracy, oraz dawałoby w uzasadnionych sytuacjach urzędowi niezbędny czas na podjęcie działań ukierunkowanych na rozwiązanie problemów związanych ze zwolnieniem, a więc na zapewnienie nowego zatrudnienia lub zwiększenie szans zwalnianych pracowników na jego uzyskanie ${ }^{32}$.

Wydaje się, że próbą kompromisu w sprawie uprawnień władzy publicznej związanych ze zwolnieniami grupowymi są uregulowania przewidziane $\mathrm{w}$ art. 70 ust. 1 ustawy $\mathrm{z}$ dnia 20 kwietnia 2004 r. o promocji zatrudnienia i instytucjach rynku pracy ${ }^{33}$, w myśl którego

31 Tamże.

32 Za nadaniem publicznym organom zatrudnienia aktywnej roli w procedurze zwolnień grupowych opowiada się między innymi K. Walczak..., s. 494; P. Czechowski, Rola publicznych służb zatrudnienia w procesie dokonywania zwolnień grupowych $w$ świetle prawa wspólnotowego i porównawczego, Praca i Zabezpieczenie Społeczne 2005, 9, s. 14.

33 Tekst jednolity Dz. U. 2016 r., poz. 645 ze zm. Zob. A. Rycak, Powszechna ochrona..., s. 156-157. 
jeżeli zwolnienie ma objąć co najmniej 50 pracowników w okresie 3 miesięcy w ramach zwolnień grupowych, jest wówczas tak zwanym zwolnieniem monitorowanym. Według art. 2 pkt 44 ustawy zwolnienie monitorowane oznacza rozwiązanie stosunku pracy lub stosunku służbowego z przyczyn dotyczących zakładu pracy, w związku z którym są świadczone usługi rynku pracy dla pracowników będących w okresie wypowiedzenia stosunku pracy lub stosunku służbowego, a także zagrożonych wypowiedzeniem.

Celem tego rozwiązania jest zaktywizowanie pracodawcy i powiatowego urzędu pracy do działań w zakresie zwolnień grupowych. W tym przypadku oprócz zawiadomienia o zamierzonym zwolnieniu grupowym powstaje kolejny obowiązek - dokonania z PUP „uzgodnien" dotyczących zakresu form pomocy dla zwalnianych pracowników, w tym pośrednictwa pracy, poradnictwa zawodowego, szkoleń. Niewykonanie tego obowiązku nie jest jednak w żaden sposób sankcjonowane przez ustawodawcę. Brak uzgodnień z powiatowym urzędem pracy nie skutkuje zatem wstrzymaniem zwolnień lub innymi konsekwencjami.

W przypadku zwolnienia monitorowanego pracodawca jest zobowiązany podjąć działania polegające na zapewnieniu pracownikom przewidzianym do zwolnienia lub będącym w trakcie wypowiedzenia lub w okresie 6 miesięcy po rozwiązaniu stosunku pracy lub stosunku służbowego usług rynku pracy realizowanych $\mathrm{w}$ formie programu. Program może być realizowany przez powiatowy urząd pracy, agencje zatrudnienia lub instytucję szkoleniową. Podmiotami finansującymi program mogą być pracodawca, pracodawca i odpowiedni organ administracji publicznej oraz na podstawie porozumienia organizacje i osoby prawne z pracodawcą.

W szczególności pracodawca, w ramach programu, może na wniosek pracownika finansować świadczenie szkoleniowe. Świadczenie szkoleniowe jest przyznawane przez pracodawcę na wniosek pracownika i przysługuje po rozwiązaniu stosunku pracy lub stosunku służbowego na czas udziału pracownika w szkoleniach w okresie nie dłuższym niż 6 miesięcy. W okresie korzystania ze świadczenia szkoleniowego zwolnionemu pracownikowi przysługuje pomoc w zakresie poradnictwa zawodowego udzielana przez właściwy dla zwolnionego pracownika powiatowy urząd pracy.

Pracownik może być także skierowany na jednorazowe szkolenie organizowane i finansowane przez powiatowy urząd pracy na zasadach określonych w ustawie. Po przyznaniu przez pracodawcę świadczenia szkoleniowego powiatowy urząd pracy refunduje pracodawcy składki na ubezpieczenia emerytalne i rentowe finansowane ze środków własnych pracodawcy, w wysokości określonej w odrębnych przepisach. Pracodawca wypłaca co miesiąc zwolnionemu pracownikowi, na podstawie zawartej z nim umowy, począwszy od miesiąca, w którym pracownik rozpoczął szkolenie, świadczenie szkoleniowe w wysokości równej wynagrodzeniu pracownika, obliczanemu jak za urlop wypoczynkowy, nie wyższej jednak niż 200\% minimalnego wynagrodzenia za pracę.

Analiza przytoczonych przepisów ustawy z 2004 r. o promocji zatrudnienia i instytucjach rynku pracy skłania do wniosku, że polski ustawodawca unika wyraźnych uregulowań, które zobowiązywałby wprost powiatowy urząd pracy do podjęcia takich działań. Brak jest także sankcji w przypadku zignorowania tego obowiązku przez pracodawcę. 


\section{Podsumowanie}

Podsumowując, mankamentem obecnie obowiązującego uregulowania dotyczącego roli władzy publicznej w sprawie zwolnienia grupowego jest jego zbytnia sztywność i formalizm w porównaniu ze standardami prawa wspólnotowego. Polski ustawodawca nie stworzył powiatowemu urzędowi pracy możliwości dostosowania się do konkretnej sytuacji, ani nie zobowiązał urzędu w sposób wyraźny, czego wymaga wspólnotowy standard, do wykorzystania czasu po zawiadomieniu go o zamiarze zwolnień przez pracodawcę do aktywnego poszukiwania sposobów na rozwiązanie problemów związanych $\mathrm{z}$ zamierzonym przez pracodawcę zwolnieniem grupowym. De lege ferenda celowe wydaje się zatem dokonanie zmian ustawy o zwolnieniach grupowych w omawianym zakresie, tak aby środek ten mógł intensywniej służyć społecznej ochronie miejsc pracy w skali lokalnych rynków pracy.

\section{Bibliografia}

Baran K.W., Procedura zwolnień grupowych, Studia z Zakresu Prawa Pracy 2003/2004.

Czechowski P., Rola publicznych stużb zatrudnienia w procesie dokonywania zwolnień grupowych wświetle prawa wspólnotowego i porównawczego, Praca i Zabezpieczenie Społeczne 2005, 9.

Dral A., Powszechna ochrona trwałości stosunku pracy. Tendencje zmian, Warszawa 2009.

Florek L., Ochrona miejsc pracy a interesy pracowników, pracodawców i bezrobotnych, w: Prawo pracy a bezrobocie, L. Florek (red.), Warszawa 2003, s. 11.

Hajn Z., Ochrona miejsc pracy a interes pracodawców, w: Prawo pracy a bezrobocie, L. Florek (red.), Warszawa 2003.

Krysińska-Wnuk L., Regulacja zwolnień grupowych pracowników, Warszawa 2009.

Rycak A., Powszechna ochrona trwałości stosunku pracy, Warszawa 2013, s. 193.

Sobczyk A., Prawo pracy w świetle Konstytucji RP, t. II, Wybrane problemy i instytucje prawa pracy a konstytucyjne prawa i wolności człowieka, Warszawa 2013.

Szewczyk H., Powszechna ochrona trwałości umownego stosunku pracy po nowelizacji kodeksu pracy, Z Problematyki Prawa Pracy i Polityki Socjalnej, t. XIII, Katowice 1998.

Szurgacz H., Dostosowanie prawa pracy do prawa europejskiego w świetle Układu Europejskiego, Państwo i Prawo 1998, 1.

Świątkowski A., Restrukturyzacja zakładu pracy. Komentarz, Kraków 2003.

Walczak K., w: Zbiorowe prawo pracy. Komentarz, J. Wratny, K. Walczak (red.), Warszawa 2009. Wypych-Żywicka A., w: System prawa pracy, t. V, Zbiorowe prawo pracy, K.W. Baran (red.), Warszawa 2014.

Słownik wspótczesnego języka polskiego, t. II, Przegląd Reader’s Digest, Warszawa 1998. Stownik wyrazów obcych. Wydanie nowe, E. Sobol (red.), Warszawa 1977. 